\title{
Purification and partial characterization of $\beta$-glucosidase from plasmodial membrane and culture medium of Physarum polycephalum
}

\author{
Masashi Morita* and Arasuke Nishi
}

Faculty of Pharmaceutical Science, Toyama Medical and Pharmaceutical University, Sugitani, Toyama 930-01, Japan

(Received 4 December 1992; revised 12 February 1993; accepted 19 February 1993)

\begin{abstract}
p-Glucosidase activity was detected in the plasma-membrane fraction of plasmodia of Physarum polycephalum. The enzyme activity was also found in the extracellular (medium) fraction after maximal growth had been attained, though the activity in this fraction was negligible during the exponential growth phase. The specific activities in both fractions were increased appreciably when the plasmodia were cultured in a glucose-free medium. The $\beta$ glucosidase was purified from the culture fluid by gel-filtration, ion-exchange and hydrophobic chromatographies. The purified enzyme appeared homogeneous on polyacrylamide-gel electrophoresis, and the molecular mass was estimated to be about $65 \mathrm{kDa}$. The enzyme showed highest activity at $\mathrm{pH} 4.5$ and at $55^{\circ} \mathrm{C}$. The $\beta$-Glucosidase from the membrane fraction showed very similar properties to that from the culture medium, suggesting that the extracellular enzyme was derived from the membrane. The enzyme was active on laminarin and lichenan as well as on $p$-nitrophenyl- $\beta$-D-glucoside; it was strongly inhibited by D-glucono-1,5-lactone, $N$-bromosuccinimide and $\mathrm{Hg}^{2+}$.
\end{abstract}

\section{Introduction}

Physarum polycephalum, a true slime mould, is a useful organism for physiological and biochemical studies on surface-localized enzymes. The plasmodium of the slime mould is a naked mass of protoplasm and it is relatively easy to isolate the plasma membrane and surface proteins without loss of their activities (Kuroda et al., 1989). In a previous paper, we reported that many glycoproteins and proteases are associated with the plasma membrane and slime polysaccharide (Morita \& Nishi, 1991). Kilpatrick \& Stirling (1977) also showed that the organism secreted various kinds of exo-glycosidase into the culture medium. They suggested that these glycosidases may be involved in the process of differentiation to macrocysts (spherules) because the activity of $\beta-N$ acetyl-D-glucosaminidase and $\beta$-glucosidase increased during spherule formation in a non-nutrient salts medium. Alternatively, the secretion of these enzymes may be part of the mechanism to locate and digest extracellular food. In this study, we examined the $\beta$ glucosidase of Physarum polycephalum which is one of the most prominent glycosidases in the plasma membrane of this organism. The present paper describes some of the factors which affect the formation and distribution

*Author for correspondence. Tel. 764342281 ext. 2636; fax 76434 4656. of $\beta$-glucosidase in $P$. polycephalum, and also reports some properties of the purified enzyme.

\section{Methods}

Cultivation of plasmodia. Axenic cultures of Physarum polycephalum were maintained as suspensions of microplasmodia in a semi-defined medium containing glucose, yeast extract and tryptone (Daniel \& Baldwin, 1964). In some cases, plasmodia were cultured in a semidefined medium lacking glucose or containing $0.5 \mathrm{M}$-mannitol (Chet \& Rusch, 1969) or in a complete synthetic medium which contains inorganic salts, 12 amino acids, two vitamins, citric acid and glucose (Daniel \& Baldwin, 1964). All culture media were autoclaved for $20 \mathrm{~min}$ at 15 p.s.i. and sterile haemin solution was then added.

The cultures were incubated at $26^{\circ} \mathrm{C}$ with shaking. Plasmodial growth was estimated by measuring the protein content of the culture. Samples were taken at regular intervals from the culture suspension and washed twice with distilled water at $4{ }^{\circ} \mathrm{C}$ by centrifugation $(750 \mathrm{~g}$, $2 \mathrm{~min}$ ) and then assayed for protein using the Lowry method with bovine serum albumin as a standard.

Preparation of plasma-membrane and extracellular fractions. Plasma membranes were prepared by the methods of Kuroda et al. (1989) with a slight modification. Microplasmodia in a $100 \mathrm{ml}$ culture suspension were collected by brief centrifugation $(750 \mathrm{~g}, 1 \mathrm{~min})$ and washed with distilled water. They were suspended in $10 \mathrm{~mm}$-Tris/ $\mathrm{HCl}$ buffer $(\mathrm{pH} 7.5)$ containing $1 \mathrm{~mm}-\mathrm{MgCl}_{2}$ and broken with 5 to 7 strokes in a Potter-type glass/Teflon homogenizer with a loose-fitting pestle. The homogenate was centrifuged at $5000 \mathrm{~g}$ for $10 \mathrm{~min}$ and the supernatant was removed to obtain the intracellular fraction. The pellet was resuspended in the same buffer and sedimented by low-speed centrifugation (100 g, $5 \mathrm{~min}$ ). The pellet was largely composed of plasma membranes (Kuroda et al., 1989), which were washed repeatedly until the supernatant became 
clear and were finally collected by centrifugation $(5000 \mathrm{~g}, 5 \mathrm{~min}$; plasma-membrane fraction). The supernatant of homogenate and washings were combined and centrifuged at $100000 \mathrm{~g}$ for $1 \mathrm{~h}$. The supernatant is referred to as an intracellular soluble fraction and the pellet as a particulate fraction.

The extracellular fraction was prepared from the culture as follows. The microplasmodia were removed from the culture medium by lowspeed centrifugation $(500 \mathrm{~g}, 2 \mathrm{~min})$ and the supernatant was recentrifuged at $15000 \mathrm{~g}$ for $30 \mathrm{~min}$ at $4{ }^{\circ} \mathrm{C}$ to remove cell debris. Proteins were sedimented by adding solid ammonium sulphate to the supernatant at a final concentration of $80 \%$ saturation. The mixture was left overnight at $4{ }^{\circ} \mathrm{C}$ and the precipitate was collected by centrifugation at $15000 \mathrm{~g}$ for $45 \mathrm{~min}$.

Glycosidase assay. Glycosidase activity was determined by the methods of Kilpatrick \& Stirling (1977). Synthetic substrates used were $p$-nitrophenyl- $\beta$-glucoside (PNP- $\beta$-glucoside), PNP- $\alpha$-glucoside, PNP$\beta$-galactoside, PNP- $\alpha$-galactoside, PNP- $\beta$ - $N$-acetylglucoside or 4methylumbelliferyl- $\beta$-glucoside (4-MUF- $\beta$-glucoside) (Nacalai tesque). The reaction was allowed to proceed for $30 \mathrm{~min}$ at $37^{\circ} \mathrm{C}$. When $4-$ MUF- $\beta$-glucoside was used as substrate, the enzyme was incubated with 4-MUF- $\beta$-glucoside solution ( $1 \mathrm{~mm}$ in $0.1 \mathrm{M}$-sodium citrate buffer, $\mathrm{pH} \mathrm{4.6)}$ in a total volume of $2 \mathrm{ml}$ for $30 \mathrm{~min}$ at $37^{\circ} \mathrm{C}$. One unit (U) of enzyme activity was defined as the amount of enzyme that liberates $1 \mu \mathrm{mol} p$-nitrophenol or 4-methylumbelliferone $\min ^{-1}$ under the assay conditions.

The activities toward various glucans were determined by the methods of Denault et al. (1978). One unit of activity is defined as the a;mount of enzyme that catalyses the release of reducing groups equivalent to $1 \mu \mathrm{mol}$ glucose $\min ^{-1}$ at $37^{\circ} \mathrm{C}$. The reducing termini of hydrolysed sugars were determined according to Lever (1972). The glucans used were lichenan $(\beta$-1,3:1,4-glucosyl); laminarin $(\beta-1,3: 1,6-$ glucosyl); carboxymethylcellulose ( $\alpha$-1,4-glucosyl); starch $(\alpha-1,4-$ glucosyl); sucrose ( $\alpha$-1,2-fructosyl); dextran T10 ( $\alpha$-1,6-glucosyl) and raffinose $(\alpha$-1,6-glucosyl, $\beta$-1,2-fructosyl).

Purification of extracellular $\beta$-glucosidase. All procedures were carried out at $4{ }^{\circ} \mathrm{C}$. Plasmodia cultured for $48 \mathrm{~h}$ in a glucose-free semidefined medium were collected by low speed centrifugation and the supernatant was recentrifuged at $15000 \mathrm{~g}$ for $30 \mathrm{~min}$ to remove cell debris. Solid ammonium sulphate was added to the supernatant to give $80 \%$ saturation. The mixture was then centrifuged at $15000 \mathrm{~g}$ for $45 \mathrm{~min}$ and the precipitate was dissolved in a small amount of $20 \mathrm{~mm}$ Tris $/ \mathrm{HCl}$ buffer ( $\mathrm{pH} \mathrm{7.3)}$ containing $0.5 \mathrm{M}-\mathrm{NaCl}$. The solution was applied to a column $(2.5 \times 50 \mathrm{~cm})$ of Sepharose CL-2B (Pharmacia). Fractions with enzyme activity were combined and applied to a column $(2.5 \times 70 \mathrm{~cm})$ of Sephadex G-100 (Pharmacia) equilibrated with $10 \mathrm{~mm}$ Tris $/ \mathrm{HCl}, \mathrm{pH} 7 \cdot 5$. The activity was found in the void fraction, which was subsequently applied to a column $(1.5 \times 10 \mathrm{~cm})$ of DEAESepharose CL-6B (Pharmacia); the column was then eluted with a linear gradient of $0-0.5 \mathrm{M}-\mathrm{NaCl}$. Solid ammonium sulphate was added to the combined active fractions to give a final concentration of $1.7 \mathrm{M}$. The mixture was then applied to a column $(1.0 \times 15 \mathrm{~cm})$ of ButylToyopearl 650 (Tosoh) equilibrated with $10 \mathrm{~mm}$-Tris/HCl, $\mathrm{pH} 7 \cdot 5$, containing $1.7 \mathrm{M}$-ammonium sulphate. The column was eluted first with the same buffer and then with a linear gradient of 1.7-0.0 M-ammonium sulphate in the same buffer. The active fractions were concentrated by ultrafiltration using a PM-10 membrane (Amicon) and again applied to a column $(1.0 \times 15 \mathrm{~cm})$ of DEAE-Sepharose CL-6B as above. The adsorbed material was eluted with a linear gradient of $0-0.4 \mathrm{M}-\mathrm{NaCl}$. After reducing the volume in an Amicon concentrator, the material was applied to a column $(1.5 \times 100 \mathrm{~cm})$ of Toyopearl HW-65 (Tosoh) equilibrated with $10 \mathrm{~mm}$-Tris $/ \mathrm{HCl}, \mathrm{pH} 7 \cdot 5$. Molecular mass markers (Sigma) were also applied to the column: $\gamma$-globulin $(158 \mathrm{kDa})$, bovine serum albumin $(66 \mathrm{kDa})$, carbonic anhydrase $(29 \mathrm{kDa})$ and cytochrome $c(12 \cdot 4 \mathrm{kDa})$.
The enzyme was also purified from the membrane fraction. The membrane fraction was suspended in 3 vols Tris/ $\mathrm{HCl}$ buffer; the final concentrations of Tris/ $\mathrm{HCl}$ and Triton $\mathrm{X}-100$ were $10 \mathrm{~mm}$ and $1 \%$ $(\mathrm{w} / \mathrm{v})$, respectively. The mixture was stirred at $4{ }^{\circ} \mathrm{C}$ for $72 \mathrm{~h}$ and centrifuged at $100000 \mathrm{~g}$ for $1 \mathrm{~h}$. The supernatant was applied to a column $(4.5 \times 43 \mathrm{~cm})$ of Toyopearl HW-75 (Tosoh) equilibrated with $10 \mathrm{~mm}$-Tris $/ \mathrm{HCl}$ buffer $(\mathrm{pH} 7.5)$ containing $0 \cdot 1 \%(\mathrm{w} / \mathrm{v})$ Triton $\mathrm{X}-100$. The active fractions were applied to a column $(1.5 \times 10 \mathrm{~cm})$ of DEAESepharose CL-6B and the column was eluted with a linear gradient of $0-0.5 \mathrm{M}-\mathrm{NaCl}$ in the same buffer containing $0 \cdot 1 \%(\mathrm{w} / \mathrm{v})$ Triton $\mathrm{X}-100$. The eluted fraction with $\beta$-glucosidase activity was collected and saved as membrane-extract fraction.

SDS-gel electrophoresis. SDS-PAGE was done according to the method of Laemmli (1970). After electrophoresis, proteins were stained with Coomassie Brilliant Blue. Molecular mass markers were myosin $(205 \mathrm{kDa}), \beta$-galactosidase $(116 \mathrm{kDa})$, phosphorylase $\mathrm{b}(97.4 \mathrm{kDa})$, bovine serum albumin $(66 \mathrm{kDa})$, ovalbumin $(45 \mathrm{kDa})$ and carbonic anhydrase $(29 \mathrm{kDa})$.

Isoelectric focusing. Fractions with $\beta$-glucosidase activity eluted from DEAE-Sepharose CL-6B were applied to a column $(1 \cdot 1 \times 16 \mathrm{~cm})$ of Polybuffer exchanger 74 (Pharmacia) equilibrated with $0.025 \mathrm{M}$ imidazole $/ \mathrm{HCl}, \mathrm{pH} 7 \cdot 4$; the column was then eluted with Polybuffer 74 (Pharmacia) at $\mathrm{pH} 4.0$. Fractions $(2 \mathrm{ml})$ were collected and their $\mathrm{pH}$ and $\beta$-glucosidase activity were determined.

\section{Results}

\section{Localization of $\beta$-glucosidase}

The distribution of $\beta$-glucosidase in plasmodial cultures of $P$. polycephalum changed as the cultures aged (Fig. 1). During the exponential growth phase, most of the activity was found in plasmodia and the increase in the

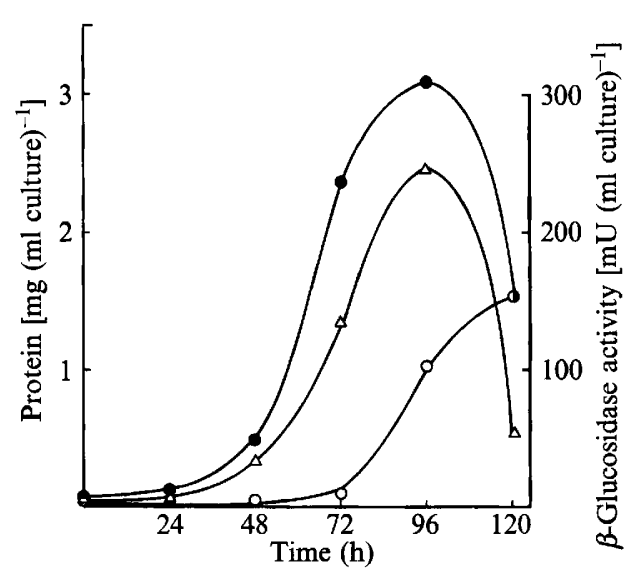

Fig. 1. $\beta$-Glucosidase activities in plasmodial and extracellular fractions of $P$. polycephalum. Microplasmodia were grown in a semi-defined liquid medium. The extracellular fraction was obtained by centrifuging the culture at $750 \mathrm{~g}$ for $2 \mathrm{~min}$. The sedimented plasmodia were suspended in $0.1 \%(\mathrm{w} / \mathrm{v})$ Triton $\mathrm{X}-100$ solution and disrupted by sonication. The suspension was saved as a plasmodial fraction. $\beta$ Glucosidase activities in the extracellular $(O)$ and plasmodial $(\triangle)$ fractions were assayed with PNP- $\beta$-D-glucoside as substrate. The protein content of the culture (O) is an indication of plasmodial growth. 
enzyme activity paralleled microplasmodial growth. The plasmodial enzymes are distributed in both cytosol and plasma membrane and the latter fraction was shown to contain various kinds of glucosidase (Morita \& Nishi, 1991). $\beta$-Glucosidases in the plasma-membrane fraction were solubilized by treatment with $1 \%(w / v)$ Triton X100 but not by $1 \mathrm{M}-\mathrm{NaCl}$ (data not shown). The enzyme activity of this fraction was increased about $1 \cdot 3$-fold when Triton X-100 $(0 \cdot 1 \%)$ was added to the reaction mixture, suggesting that the membrane-bound enzyme might be partially cryptic. In the exponential growth phase (48-72 h, Fig. 1), about $37 \%$ of the total activity was found in the plasma-membrane fraction and, as mentioned above, only a weak activity was detected in the culture medium. After cessation of growth $(120 \mathrm{~h}$, Fig. 1), however, more than $40 \%$ of the total activity was found in the medium while about $14 \%$ of the activity was in the membrane fraction. This was not caused by lysis of plasmodia in aged cultures because there was little increase in the absorption at $260 \mathrm{~nm}$ of these culture media, indicating that there was not a general release of cellular material. These results show that the distribution of the $\beta$-glucosidase between intra- and extracellular spaces may change according to growth stage.

\section{$\beta$-Glucosidase activities in different media}

$\beta$-Glucosidase activity in the extracellular fraction was influenced by the composition of the medium (Fig. 2). During the experimental period used, plasmodia grew exponentially except for those cultured in mannitol medium. The doubling times for plasmodial growth in

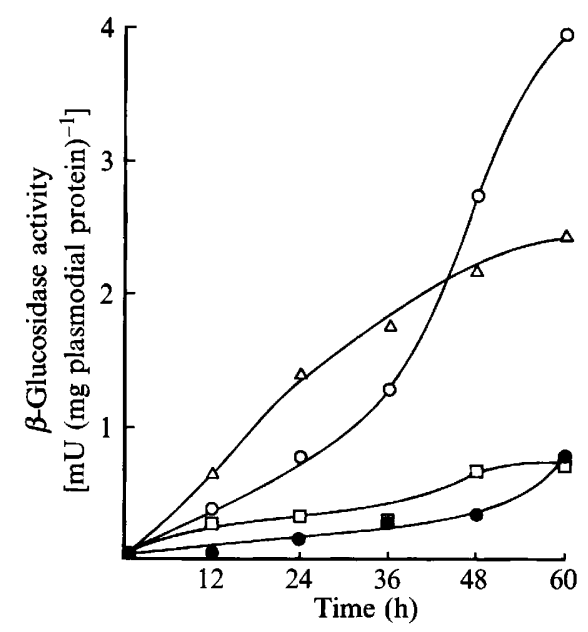

Fig. 2. Extracellular $\beta$-glucosidase activities in different media. Plasmodia previously grown in the semi-defined complete medium were washed and resuspended in semi-defined medium (O), mannitolcontaining medium $(\triangle)$, glucose-free semi-defined medium $(O)$, or synthetic medium, $(\square)$. $\beta$-Glucosidase activity was assayed with PNP$\beta$-D-glucoside. the semi-defined, glucose-free semi-defined and synthetic media were about $9 \mathrm{~h}, 14 \mathrm{~h}$ and $30 \mathrm{~h}$, respectively. The most abundant enzyme production (based on activity per mg plasmodial protein) was observed in the semi-defined glucose-free medium. On the other hand, in media containing glucose, the extracellular activity was always very low. It is conceivable that the synthesis and the release of $\beta$-glucosidase to the medium is regulated by the content of glucose in the medium. This idea is consistent with the result in Fig. 1 showing that the plasmodia in an aged culture medium, in which glucose was largely exhausted, released large amounts of $\beta$-glucosidase to the extracellular medium. We also found that the addition of glucose to the culture in the semi-defined culture-free medium resulted in a decrease in the intra- and extracellular enzyme activities per plasmodium (data not shown). When plasmodia were incubated in a mannitol medium in which the plasmodia underwent spherule formation, the extracellular $\beta$-glucosidase activity was relatively high.

A similar increase in $\beta$-glucosidase activity was found in the plasma-membrane fraction when the plasmodia were cultured in the glucose-free medium. In the semidefined medium, the specific activity of plasmamembrane enzyme at exponential phase was $167 \mathrm{mU}$ $(\mathrm{mg} \text { protein })^{-1}$. When the plasmodia were cultured in the glucose-free medium, it increased to $387 \mathrm{mU}$ (mg protein) ${ }^{-1}$. Unlike the extracellular enzyme, however, the membrane-bound enzyme decreased appreciably when the culture entered the stationary phase $[99 \mathrm{mU}(\mathrm{mg}$ protein) ${ }^{-1}$. Enzyme activities in the intracellular soluble and particulate fractions did not show any significant change during the culture. It is conceivable, therefore, that the enzymes associated with the plasma membrane were gradually released to the extracellular medium after the cessation of growth.

It should be noted that the specific activity of the enzyme in the membrane fraction was significantly decreased when the plasmodia were transferred from the semi-defined medium to mannitol medium. Within $12 \mathrm{~h}$, the specific activity had decreased to $54 \mathrm{mU}$ (mg protein $^{-1}$.

When the plasmodia were continuously cultured in a synthetic medium, the specific activity of $\beta$-glucosidase in the plasma-membrane fraction was only about $50 \mathrm{mU}$ (mg protein) $^{-1}$, which was significantly less than that of plasmodia grown in the semi-defined medium [167 mU (mg protein) $)^{-1}$. Addition of tryptone to the synthetic medium at the final concentration of $1 \%(\mathrm{w} / \mathrm{v})$ resulted in an increase in the enzyme activity. After incubation for $48 \mathrm{~h}$, the specific activity rose to more than $100 \mathrm{mU}$ $(\mathrm{mg} \text { protein })^{-1}$. A similar result was obtained when the medium was supplemented with yeast extract. However, the addition of an amino acid mixture to the culture 
Table 1. Purification of $\beta$-glucosidase from glucose-free semi-defined medium of plasmodia

\begin{tabular}{|c|c|c|c|c|c|}
\hline $\begin{array}{l}\text { Purification } \\
\text { step }\end{array}$ & $\begin{array}{l}\text { Protein } \\
(\mathrm{mg})\end{array}$ & $\begin{array}{l}\text { Total } \\
\text { activity } \\
\text { (U) }\end{array}$ & $\begin{array}{l}\text { Specific } \\
\text { activity } \\
\left(\mathrm{U} \mathrm{mg}^{-1}\right)\end{array}$ & $\begin{array}{l}\text { Purification } \\
\text { (-fold) }\end{array}$ & $\begin{array}{c}\text { Recovery } \\
(\%)\end{array}$ \\
\hline \multicolumn{6}{|l|}{$\left(\mathrm{NH}_{4}\right)_{2} \mathrm{SO}_{4}$} \\
\hline Sepharose CL-2B & $24 \cdot 9$ & $3 \cdot 24$ & $0 \cdot 130$ & 1.9 & 61 \\
\hline Sephadex G-100 & $5 \cdot 82$ & $2 \cdot 56$ & 0.44 & $6 \cdot 4$ & 48 \\
\hline \multicolumn{6}{|l|}{ DEAE-Sepharose } \\
\hline CL-6B & $1 \cdot 43$ & 1.39 & 0.972 & $14 \cdot 1$ & 26 \\
\hline Butyl-Toyopearl & $0 \cdot 162$ & $0 \cdot 502$ & $3 \cdot 10$ & 44.9 & $9 \cdot 5$ \\
\hline \multicolumn{6}{|l|}{ DEAE-Sepharose } \\
\hline CL-6B & $0 \cdot 117$ & 0.467 & 3.99 & 57.8 & $8 \cdot 8$ \\
\hline Toyopearl HW-65 & $0 \cdot 105$ & 0.586 & $5 \cdot 58$ & $80 \cdot 9$ & $10 \cdot 7$ \\
\hline
\end{tabular}

medium did not cause an increase in enzyme activity. Attempts to identify the components in tryptone and yeast extract which accelerate the production of $\beta$ glucosidase were not successful.

\section{Purification of $\beta$-glucosidase}

The culture fluid of the glucose-free semi-defined medium in which the plasmodia had been grown for $48 \mathrm{~h}$ was used as starting material for isolation of extracellular $\beta$ glucosidase. The enzyme was purified about 80 -fold with $10 \%$ recovery (Table 1 ). To remove slime components, which interfered with chromatographic separation, the culture medium was first treated with ammonium sulphate and the precipitate was applied to a column of Sepharose CL-2B. Active fractions were then applied on to a column of Sephadex G-100. Most of the activity was excluded from the column and was found in the void volume. The enzyme was further purified by ionexchange, hydrophobic and gel-filtration chromatographies.

The purified enzyme was electrophoretically homogeneous (data not shown). The apparent molecular mass estimated by Toyopearl HW-65 filtration and SDSPAGE was about $65 \mathrm{kDa}$. On a chromatofocusing column, the enzyme appeared to have a $\mathrm{pI}$ of about $5 \cdot 25$ (data not shown). About $70 \%$ of the $\beta$-glucosidase activity was found to be retained in a Con A-Sepharose column and desorbed with a buffer containing $\alpha$ methylmannoside or $\alpha$-methylglucoside, suggesting that the enzyme is a glycoprotein.

Membrane-associated $\beta$-glucosidases were extracted with a buffer containing Triton X-100 and purified by similar chromatographic methods. The extract was subjected to gel-filtration with Toyopearl HW-75 to dissociate $\beta$-glucosidase from slime material. The fractions with $\beta$-glucosidase activity were then applied to a column of DEAE-Sepharose CL-6B. The enzyme activity was found in a single peak in the elution profile and was referred to as a membrane-extract fraction.

\section{Characterization of purified $\beta$-glucosidase}

$\beta$-Glucosidases prepared from the medium and membrane fractions showed the same $\mathrm{pH}$ optimum at about 4.5 (Fig. $3 a$ ). The optimum temperature for the activity of these enzymes was about $55^{\circ} \mathrm{C}$ (Fig. $3 b$ ). The thermostability study at $\mathrm{pH} 7.5$ indicated that the enzyme purified from the medium fraction was rather unstable at the optimum temperature for its fraction $\left(55^{\circ} \mathrm{C}\right)$. The enzyme lost $50 \%$ of the activity after $1 \mathrm{~h}$ at $50^{\circ} \mathrm{C}$ and total loss was observed within $10 \mathrm{~min}$ at $60^{\circ} \mathrm{C}$. On the other hand, the $\beta$-glucosidase preparation from the membrane fraction was somewhat more stable than that from the medium.

A variety of compounds were examined as potential substrates of the purified extracellular enzyme. The enzyme was capable of cleaving glucosidic linkage in PNP- $\beta$-glucoside (relative activities, $100 \%$ ), laminarin $(31.8 \%)$, lichenan $(15.2 \%)$ and 4 -MUF- $\beta$-glucoside $(27 \cdot 4 \%)$. Almost no hydrolytic activity was observed when PNP- $\alpha$-glucoside $(1.7 \%)$, PNP- $\beta$ - $N$-acetylglucosaminide ( $0.6 \%)$, PNP- $\alpha$-galactoside $(0.4 \%)$ and PNP- $\beta$ galactoside $(0.7 \%)$ were used as substrates. Carboxymethylcellulose, starch, sucrose, dextran T10 and raffinose were not susceptible to the enzyme. The membrane-extract also showed hydrolytic activity on laminarin at a rate similar to the purified extracellular enzyme. Both $\beta$-glucosidases have an identical $K_{\mathrm{m}}$ value of approximately $5-7 \times 10^{-4} \mathrm{M}$ toward PNP- $\beta$-glucoside at $\mathrm{pH} 4 \cdot 6$.

Among various reagents tested, $N$-bromosuccinimide, $\mathrm{HgCl}_{2}$ and D-glucono-1,5-lactone appeared to be the most potent inhibitors of the enzyme (Table 2). Complete inhibition of the enzyme was observed in the presence of $10 \mathrm{mM}$-D-glucono-1,5-lactone which is a known inhibitor 


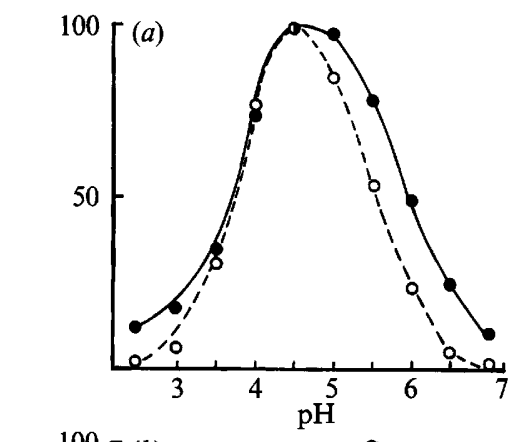

Table 2. Effect of inhibitors on $\beta$-glucosidase activity

Purified enzymes from medium and membrane extract were preincubated at room temperature with inhibitor for $30 \mathrm{~min}$ and the activity was determined using PNP- $\beta$-D-glucoside as substrate. The control value obtained without inhibitor $\left(1.40 \mathrm{U} \mathrm{mg}^{-1}\right.$ and $0.22 \mathrm{U} \mathrm{mg}^{-1}$ for extracellular and membrane enzymes, respectively) was taken as $100 \%$. Repeated experiments gave similar results and representative results are shown.

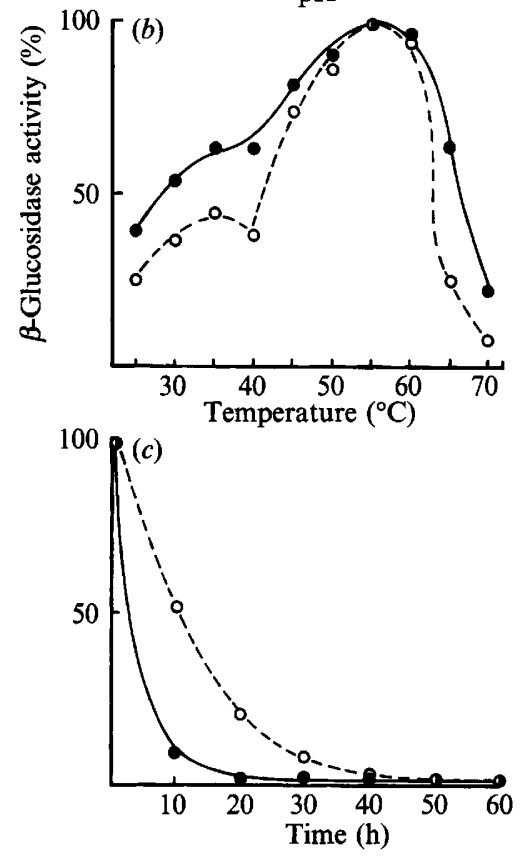

Fig. 3. Properties of $\beta$-glucosidase purified from medium (O) or membranes (O). (a) Effect of $\mathrm{pH}$ on the enzyme activity. The enzymes were assayed in citrate-phosphate buffer (Gomori, 1955) of various pHs with PNP- $\beta$-D-glucoside as substrate for $30 \mathrm{~min}$ at $37^{\circ} \mathrm{C}$. The maximal activity obtained at $\mathrm{pH} 4.5\left(1.40 \mathrm{U} \mathrm{mg}^{-1}\right.$ and $0.22 \mathrm{U} \mathrm{mg}^{-1}$ for extracellular and membrane enzymes, respectively) was set as $100 \%$. (b) Effect of temperature on the enzyme activity. The enzymes were assayed at various temperatures from $25^{\circ} \mathrm{C}$ to $70^{\circ} \mathrm{C}$ for $30 \mathrm{~min}$ at pH 4.6. The maximal activity obtained at $55^{\circ} \mathrm{C}$ was set as $100 \%$. (c) Thermostability of $\beta$-glucosidase at $\mathrm{pH} 7.5$. The enzymes were preincubated at $55^{\circ} \mathrm{C}$. An aliquot of the sample was removed periodically and the residual enzyme activity was measured.

of exo- $\beta$-glucanase (Conchie, 1954). $\mathrm{Hg}^{2+}$ and bromosuccinimide, both of which act on $\mathrm{SH}$ groups, affected the activity, indicating that thiol groups are present in the active site of the enzyme or that these groups are important in maintaining the enzyme structure. Similar results were obtained when the inhibitory effect of these reagents were tested on the membrane extracts. Cations such as $\mathrm{CaCl}_{2}, \mathrm{MgCl}_{2}$ and $\mathrm{MnCl}_{2}$ showed little effect on $\beta$-glucosidase activity though the enzyme purified from the medium was inhibited to some extent by the presence of EDTA.

\begin{tabular}{|c|c|c|c|}
\hline Inhibitor & Concn & $\begin{array}{c}\text { Purified } \\
\text { extracellular } \\
\beta \text {-glucosidase } \\
(\%)\end{array}$ & $\begin{array}{c}\text { Membrane } \\
\text { extracts } \\
(\%)\end{array}$ \\
\hline \multirow[t]{2}{*}{$\mathrm{HgCl}_{2}$} & $10 \mathrm{~mm}$ & 7 & 17 \\
\hline & $1 \mathrm{~mm}$ & 43 & 56 \\
\hline \multirow[t]{2}{*}{$\mathrm{N}$-Bromosuccinimide } & $10 \mathrm{~mm}$ & 0 & 2 \\
\hline & $1 \mathrm{~mm}$ & 0 & 2 \\
\hline \multirow{2}{*}{$\beta$-Mercaptoethanol } & $2000 \mathrm{mM}$ & 114 & 39 \\
\hline & $500 \mathrm{~mm}$ & 112 & 86 \\
\hline$N$-Ethylmaleimide & $10 \mathrm{~mm}$ & 102 & 98 \\
\hline \multirow[t]{2}{*}{ D-Glucono-1,5-lactone } & $10 \mathrm{~mm}$ & trace & 3 \\
\hline & $1 \mathrm{~mm}$ & 2 & 9 \\
\hline $\mathrm{CaCl}_{2}$ & $10 \mathrm{~mm}$ & 92 & 97 \\
\hline EDTA & $10 \mathrm{~mm}$ & 40 & 101 \\
\hline \multirow[t]{2}{*}{ Sodium dodecyl sulphate } & $1 \%$ & 119 & 99 \\
\hline & $0 \cdot 1 \%$ & 129 & 99 \\
\hline
\end{tabular}

\section{Discussion}

Our previous study (Morita \& Nishi, 1991) showed that $\beta$ - $N$-acetylhexosaminidase and $\beta$-glucosidase were detectable in both the slime fraction and plasma membrane from Physarum polycephalum. In the present study, we have dealt with the forms of $\beta$-glucosidase which are membrane bound and secreted into the medium. The distribution of the enzyme activities in these fractions changed according to the culture condition and the stage of plasmodial growth. A large increase in enzyme activity was found when glucose was removed from the culture medium or glucose had been consumed. It has been reported that glucose represses the synthesis of $1,3-\beta$ glucanase in Neurospora crassa (Rey et al., 1979; Friebe \& Holldorf, 1975). In Monilia sp. (Dekker, 1981), Schizophyllum commune (Wilson \& Niederpruem, 1967) and Penicillium italicum (Santos et al., 1977; Sanchez et al., 1982), the synthesis of extracellular $\beta$-glucosidase appears to be strictly regulated by the levels of glucose. It is likely that plasmodia secrete the enzyme to mobilize carbon sources when glucose is no longer available in the culture medium. The repression and derepression processes of the two forms of the $\beta$-glucosidase by glucose were similar, suggesting that the production of these two enzymes is regulated by an identical mechanism.

Plasmodia grown in the mannitol medium are destined to differentiate into spherules which are covered by a hard cell wall and under these conditions the $\beta$ glucosidase activity in the membrane fraction was 
significantly decreased. It appears that the enzyme associated with the plasma membrane is no longer required in these dormant cells.

When plasmodia were incubated in the synthetic medium, the enzyme activity in the membrane fraction became very low. The activity was increased by the addition of tryptone or yeast extract to the synthetic culture medium. There have been many reports showing that the synthesis of glucosidase is promoted by some carbohydrates (Wilson \& Niederpruem, 1967; Kusama et al., 1986; Strauss \& Kubicek, 1990). Dekker (1981) reported that the extracellular $\beta$-glucosidase of Monilia sp. was induced by cellulose but repressed by cellobiose while intracellular and mycelial-bound enzymes were induced by both cellulose and cellobiose. It is known that yeast extract contains some glucans (Carlile, 1970) which might be degraded and utilized by plasmodia as a carbon source. However, the specific activity was not significantly increased when the plasmodia were cultured in a medium containing laminarin or lichenan (data not shown). A search for active inducing substances is still in progress in our laboratory.

The enzyme in the extracellular medium showed striking similarities to the membrane enzyme with respect to $\mathrm{pH}$-activity profile, temperature dependency, substrate specificity and sensitivity to inhibitors. In addition, the apparent $K_{\mathrm{m}}$ values of these enzymes for synthetic substrates were almost identical. These results suggest that the extracellular enzymes were derived from the membrane-bound $\beta$-glucosidase. In growing plasmodia, the cell surface is covered by slime polysaccharides and they form a membrane-slime complex. We have reported that the slime substances are released into the culture medium together with certain glycoproteins and proteases when plasmodia reach maximal growth in shaken culture (Morita \& Nishi, 1991). It is possible that the membrane-bound $\beta$-glucosidases are also released into the medium.

It should be noted, however, that the bound $\beta$ glucosidase was only solubilized from the membrane in the presence of detergent, suggesting that the enzyme is tightly bound to the plasma membrane. The solubilized enzyme molecules may still contain hydrophobic moieties because they tended to make aggregates when the detergent was removed from the solution. By contrast, the extracellular enzymes were completely soluble in water. These observations, together with the fact that the mobility of these two enzymes was not the same in SDSPAGE (unpublished observations), suggests that the release of the enzymes from the membrane, if any, requires certain biochemical modification of the enzyme molecules.

The purified $\beta$-glucosidase showed the highest hydrolytic activity to laminarin and lichenan and was strongly inhibited by 1,5-glucono-D-lactone, suggesting that the purified $\beta$-glucosidase is exo- $\beta$-1,3-glucanase which is widely distributed in bacteria, fungi and higher plants (Notario et al., 1976; Copa-Patino et al., 1989; Kurosaki et al., 1991).

It appears that the plasmodia of $P$. polycephalum can use $\beta$-1,3-glucans as carbon source. This is consistent with the report that a $\beta$-1,3-linked glucan with $\beta$-1,6branches from Claviceps fusiformis can be substituted for glucose as carbon source in plasmodial culture (Carlile, 1970). It is conceivable, therefore, that localization of $\beta$ glucosidase to the plasmodial surface is advantageous to the slime mould to mobilize the carbon source from the natural environment around the plasmodia.

It has been reported that microbial glycosidases are sometimes involved in the process of differentiation. For example, in Polysphondylium (O'Day \& Paterno, 1979) and Schizophyllum commune (Wilson \& Niederpruem, 1967), $\beta$-glucosidase has been implicated in the germination of macrocysts and basidiospores, respectively. It is not clear, at present, whether the $\beta$-glucosidases in $P$. polycephalum participates in any of morphogenetic events during the life cycle of the slime mould.

We thank H. Okuda, S. Tamura and Y. Saitoh for expert technical assistance.

\section{References}

Carlile, M. J. (1970). Nutrition and chemotaxis in the myxomycete Physarum polycephalum: the effect of carbohydrates on the plasmodium. Journal of General Microbiology 63, 221-226.

ChET, I. \& Rusch, H. P. (1969). Induction of spherule formation in Physarum polycephalum by polyols. Journal of Bacteriology 100 , 673-678.

CONCHIE, J. (1954). $\beta$-Glucosidase from rumen liquor. Biochemical Journal 58, 552-560.

Copa-Patino, J. L., Reyes, F. \& Perez-Leblic, M. I. (1989). Purification and properties of a 1,3- $\beta$-glucanase from Penicillum oxalicum autolysates. FEMS Microbiology Letters 65, 285-292.

DaNiEL, J. W. \& Baldwin, H. H. (1964). Axenic culture of Physarum polycephalum on soluble media. Methods in Cell Physiology 1, 9-14.

DEKKER, R. F. H. (1981). Induction, localization and characterization of $\beta$-D-glucosidases produced by a species of Monilia. Journal of General Microbiology 127, 177-184.

Denault, L. T., Allen, W. G., Boyer, E. W., Collins, D., Kramme, D. \& Spradlin, J. E. (1978). A simple reducing sugar assay for measuring $\beta$-glucanase activity in malt, and various microbial enzyme preparations. Journal of the American Society of Brewing Chemists 36, $18-23$.

Friebe, B. \& Holldorf, A. W. (1975). The control of extra cellular 1,3$\beta$-glucanase activity in the Basidiomycete species QM 806. Biochemical Society Transactions 994-996.

GOMORI, G. (1955). Preparation of buffers for use in enzyme studies. Methods in Enzymology 1, 138-146.

Kilpatrick, D. C. \& Stirling, J. L. (1977). Glycosidases from the culture medium of Physarum polycephalum. Biochemical Journal 161, 149-157.

Kuroda, T., Morita, M., Okai, K., Okamura, S. \& Nishi, A. (1989). Isolation of plasma membrane and analysis of membrane glycoproteins from the slime mould Physarum polycephalum. Journal of General Microbiology 135, 873-881. 
Kurosaki, F., Tokitoh, Y. \& Nishi, A. (1991). Purification and characterization of wall-bound $\beta$-1,3-glucanases in cultured carrot cells. Plant Science 77, 21-28.

Kusama, S., Kusakabe, I. \& Murakami, K. (1986). Purification and some properties of $\beta$-1,3-glucanase from Streptomyces sp. Agricultural and Biological Chemistry 50, 1101-1106.

LaEMmLI, U. K. (1970). Cleavage of structural proteins during the assembly of the head of bacteriophage T4. Nature, London 227, 680-685.

LEVER, M. (1972). A new reaction for colorimetric determination of carbohydrates. Analytical Biochemistry 47, 273-279.

MoRITA, M. \& NiSHI, A. (1991). Glycoproteins and enzymes associated with the plasmodial membrane and slime layer of Physarum polycephalum. Journal of General and Applied Microbiology 37, 93-109.

Notario, V., Villa, T. G. \& Villanueva, J. A. (1976). Purification of an exo- $\beta$-glucanase from cell-free extracts of Candida utilis. Biochemical Journal 159, 555-562.

O'DAY, D. H. \& PATERNO, G. D. (1979). Intracellular and extracellular
CM-cellulase and $\beta$-glucosidase activity during germination of Polysphondylium pallidum microcysts. Archives of Microbiology 121, 231-234.

Rey, F. D., Garcia-Acha, I. \& Nombela, C. (1979). The regulation of $\beta$-glucanase synthesis in fungi and yeast. Journal of General Microbiology 110, 83-89.

Sanchez, M., Nombela, C., Villanueva, J. R. \& Santos, T. (1982). Purification and partial characterization of a developmentally regulated 1,3- $\beta$-glucanase from Penicillium italicum. Journal of General Microbiology 128, 2047-2053.

Santos, T., Villanueva, J. R. \& Nombela, C. (1977). Production and catabolite repression of Penicillium italicum $\beta$-glucanases. Journal of Bacteriology 129, 52-58.

Strauss, J. \& KubiCEK, P. (1990). $\beta$-Glucosidase and cellulase formation by a Trichoderma reesei mutant defective in constitutive $\beta$-glucosidase formation. Journal of General Microbiology 136, 1321-1326.

WILSON, R. W. \& NIEDERPRUEM, D. J. (1967). Control of $\beta$-glucosidases in Schizophyllum commune. Canadian Journal of Microbiology 13, 1009-1020. 